\title{
NOTES ON THE CARNIVOROUS TENDENCIES OF SOME SCIURIDS
}

\author{
by Spencer G. Sealy, Battleford
}

The animals known as rodents are the most successful of modern mammals next to man. They have exploited ecological niches on land, under the ground, in trees, and some in water. They are mostly herbivorous with structural adaptations to meet this end; however, carnivorous propensities occasionally show up among them. This note presents observations on the meat-eating tendencies of the rodent family Sciuridae, the squirrels.

The meat-eating tendencies of the Ground Squirrel (Citellus lyratus) have been documented by Geist (1933) and Cade (1951) on St. Lawrence Island, Alaska. Both authors reported this species feeding on other ground squirrels as well as other animals. Hanson, et. al. (1956) observed the Parry's Ground Squirrel (C. parryii) feeding on a bird carcass near the Perry River, Northwest Territories, and on two occasions in July, 1965, I observed the same species eating other ground squirrels which had been shot near the Gavin River, a tributary of the Perry River. On August 4, 1965, J. P. Ryder (pers. comm.) observed it feeding on another Parry's Ground Squirrel on the bank of the Ekalukpik River, about 30 miles east of the Perry River. Wilber and Mussachia (1950) in discussing aspects of fat metabolism in the Arctic Ground Squirrel (C. barrowensis) in Alaska, pointed out that it "thrives in its northern habitat and hence it must have solved the problem of balancing the budget of heat loss versus heat production." According to Cade (op. cit.) "if more animal fats are eaten by Arctic ground squirrels than is commonly supposed, this fact would seem to be equally important in explaining the relatively high level of production and storage in Arctic ground squirrels as an adaptive phy- siological mechanism for the more efficient synthesis of fats."

During the winters of 1959-1960 and 1960-1961 while weasel trapping in the Battleford area, Saskatchewan, I successfully trapped the Red Squirrel (Tamiasciurus hudsonicus) by employing the method used for weasels; that was a "cubby" with portions of meat placed behind a trap or on its pan. It was thought that the squirrels were "curious" and investigated the cubby on that basis, accidentally becoming caught, but this was found not to be the case entirely, for seven out of nine stomachs examined from specimens collected in this manner contained quantities of meat (the squirrels being caught before having a chance to feed on the bait could account for the stomachs devoid of meat). The remaining stomachs contained vegetable matter and it is presumed that this would constitute the bulk of its winter diet as animal matter would seemingly be unavailable.

During the summer of 1963 in the Brooks area, Alberta, the Richardson's Ground Squirrel (C. richardsonii) was observed on numerous occasions feeding on road-killed "gophers" and, in one instance on a White-tailed Jackrabbit (Lepus townsendii). As many as four were seen feeding on a victim at one time. This habit, practised by adults and young, increased their vulnerability, for they seemed to pay no attention to oncoming cars and three or four dead ones were often seen within a few inches of each other on the road, presumably killed while consuming a previously killed animal.

On June 8, 1964 at Gorge Creek, Alberta, a Columbian Ground Squirrel (C. columbianus) was observed for three minutes feeding on a carcass of one of its own species at the entrance 
to a burrow. I do not know the cause of death of the animal being eaten but it would seem unlikely that cannibalism occurred or occurs in any rodent species except perhaps under severe populational stress.

I have no observations indicating whether any of these species actually pursue other animals with the intent to kill for food. Sowls (1948) found the Franklin's Ground Squirrel ( $C$. franklinii) to be a predator upon the eggs of many waterfowl species at Delta, Manitoba, and Soper (1964: 143) states that individuals of this species have been known to kill and eat small rodents, native birds and chickens. Johnson (1922) tells of an incident whereby a Franklin's Ground Squirrel struggled with, killed, and devoured a young rabbit in northern Minnesota. J. Wilson, Indian Head, Saskatchewan (in Blue Jay, 2(4) :32, 1944) saw a Franklin's Ground

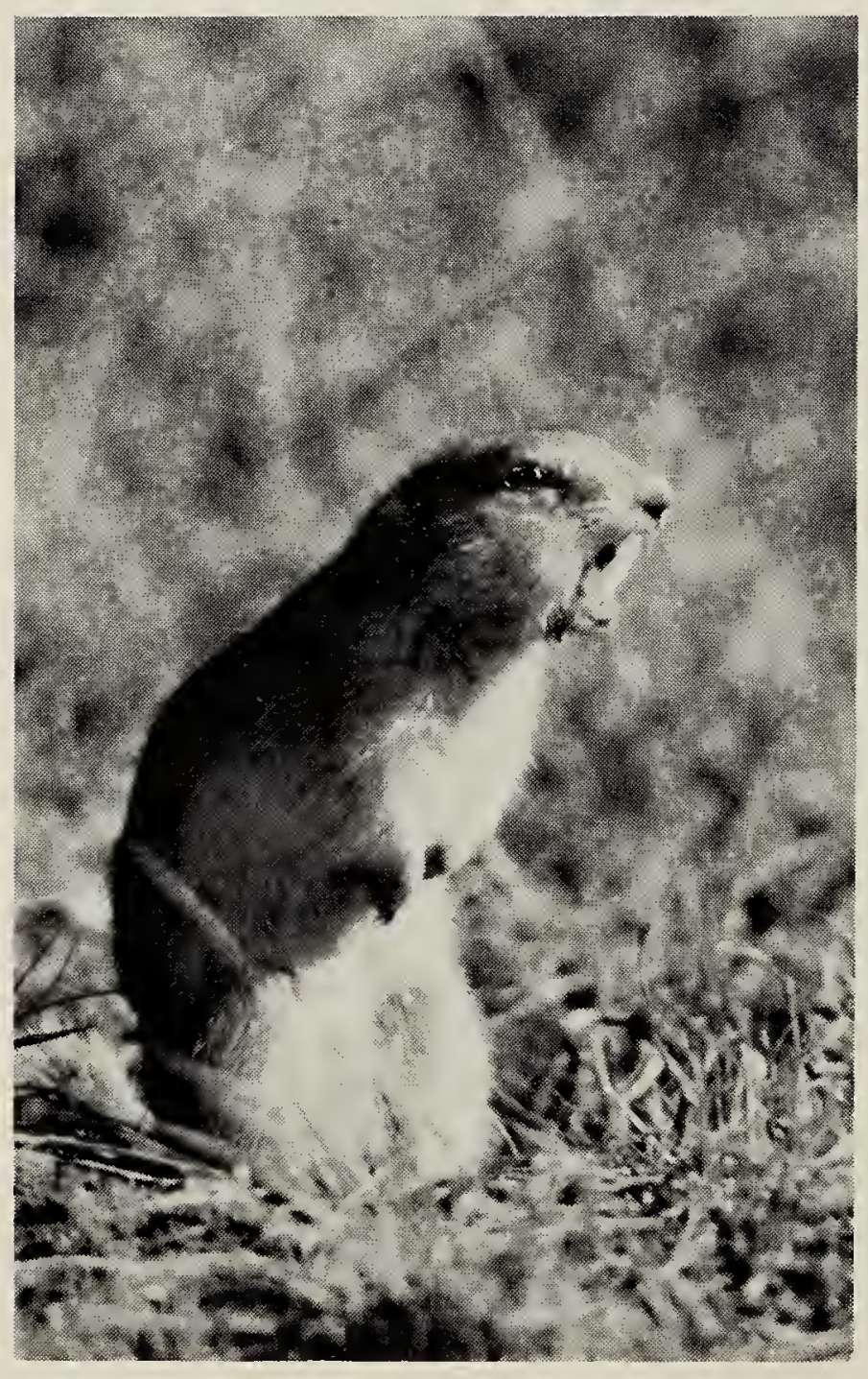

Photo by Robert R. Taylor Richardson's Ground Squirrel
Squirrel, "standing erect, hold a prairie chicken's egg against its body with its front legs, and bend forward until the pressure, thus exerted, cracked the egg." Emlen and Glading (1938) report a case where a California Ground Squirrel (C. beecheyi) robbed a nest of the Valley Quail (Lophortyx californica vallicola) on May 17, 1937. H. H. Pitman (in Blue Jay, 2(4):32, 1944) once saw a Thirteen-lined Ground Squirrel (C. tridecemlineatus) "turning over the eggs in a prairie chicken's nest and even rolling over on its back clasping one in a probable attempt to break the shell."

It would be interesting to compare fat production, metabolism and storage in the Arctic and temperate ground squirrels and to note differences, if any persist, regarding their periods of activity and hibernation in these diverse climatic pressures. It would also be interesting to examine Citellus of the sub-tropics where aestivation commonly occurs during the hottest period of the year to see if its bioenergetics differ appreciably from its northern counterparts.

\section{LITERATURE CITED}

Cade, T. 1951. Carnivorous ground squirrels on St. Lawrence Island, Alaska. Jour. Mamm., 32 :358-360.

Emlen, J. T., and B. Glading. 1938. California ground squirrel robs nest of valley quail. Condor, 40:41-42.

Geist, O. W. 1933. Habits of the ground squirrel Citellus lyratus on St. Lawrence Island, Alaska. Jour. Mamm., 14 :306-308.

Hanson, H. C., P. Queneau, and P. Scott. 1956. The geography, birds and mammals of the Perry River region. Arctic Inst. N. Am. Spec. Pub. No. 3.

Johnson, A. 1922. Notes on the carnivorous propensities of the gray gopher. Jour. Mamm., $3: 187$.

Soper, J. D. 1964. The mammals of Alberta. Hamley Press, Edmonton. 402 pp.

Sowls, L. K. 1948. The Franklin ground squirrel, Citellus franklinii (Sabine), and its relationship to nesting ducks. Jour. Mamm., 29 :113-137.

Wilber, C. G., and X. J. Mussachia. 1950. Fat metabolism in the Arctic ground squirrel. Jour. Mamm., 31:304-309. 


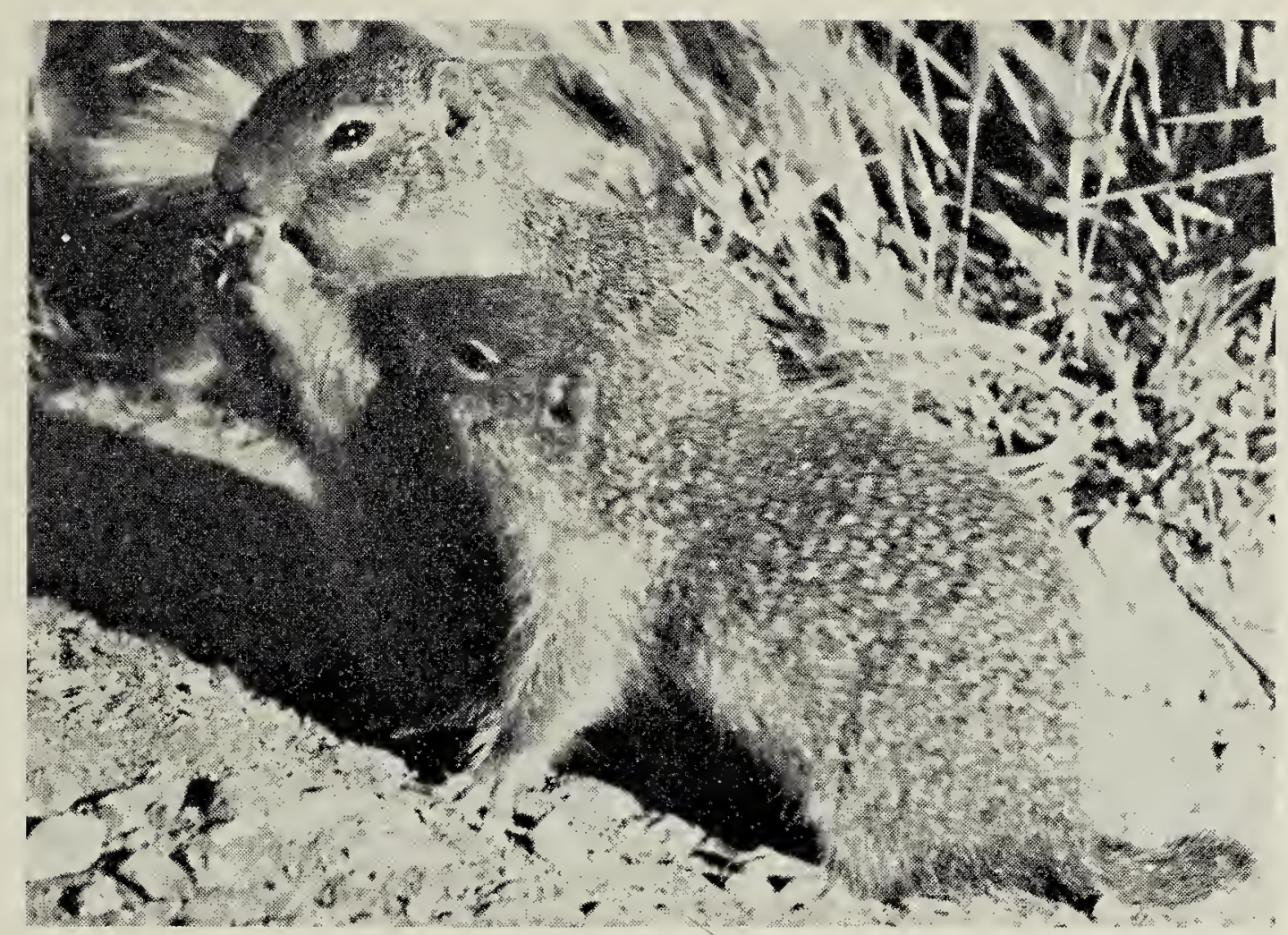

Columbian Ground Squirrels

Photo by Kay Hodges

\section{RETURN OF BISON TO MANITOBA}

Hon. Arthur Laing, Minister of Northern Affairs and National Resources and Hon. Sterling R. Lyon, Q.C., Minister of Mines and Natural Resources of Manitoba, in a joint release, said today that a herd of 20 plains buffalo from Elk Island $\mathrm{Na}$ tional Park in Alberta will be settled in the new 500,000-acre Mawdesley Wildlife Management area east of The Pas. This is a pilot project being carried out jointly by the Manitoba Department of Mines and Natural Resources and the Canadian Wildlife Service to find out if buffalo can survive in the wild again in Manitoba.

The area chosen for the release of the bison lies between Moose Lake and Mawdesley Lake. It was selected after reconnaissance surveys of several possible sites by federal bison experts. It contains habitat similar to that which supports plains bison in the Alberta portion of Wood Buffalo National Park. While climate and vegetation appear to be suitable, only a prolonged and intenrive biological study can determine with certainty if bison can thrive in the area. Rather than wait for such a study, Mr. Lyon said, it was decided to release a small experimental herd and observe how they adapt to their new surroundings.

If the first release is successful, a second and larger release will be made in future, the Ministers said.

There is evidence that bison did occasionally inhabit the area at one time. Buffalo bones have been found near where the release will be made and the native people can recall stories of buffalo hunts in the area told by their forefathers.

These buffalo are being selected from the anthrax-free Elk Island herd. The buffalo are being released in an isolated area where there is no chance of them coming in contact with domestic stock.

If successful this experiment will see the return to Manitoba of one of its largest and most exciting wildlife attractions, Mr. Lyon said. The original herds were shot out and their habitat destroyed during the early settlement of the Province. Mr. Lyon said the re-introduction of the buffalo will return it to its natural home. The first release of the animals is expected late next year. 